\title{
Influence of Brand Credibility, Satisfaction and Quality on Brand Equity in Non-Conventional Health
} Industry

\author{
Peter Kwasi Oppong \\ Cape Coast Technical University, Cape Coast, Ghana \\ peteroppong72@gmail.com
}

\begin{abstract}
Consumer perceptions of quality, satisfaction, and brand credibility are critical ingredients for developing healthy brands with high value in a competitive market. However, few authors have looked into the brand credibility`s intervening role in the effect of quality and satisfaction on brand equity in the nonconventional health industry. Hence, this paper sought to evaluate the mediating role of brand credibility in the effect of quality and satisfaction on brand equity in the non-conventional health industry. A covariancebased structural equation model was the analytical tool employed to evaluate the hypotheses stated in this paper. Data were gathered from 265 customers using a systematic sampling technique. The research confirmed that brand credibility contributes partially to the impact of quality on brand equity and completely to satisfaction on equity in the non-conventional health industry. Accordingly, this paper contributes to expanding the current brand management literature by demonstrating the brand credibility`s intervening role in the path between satisfaction, quality, and equity, particularly in the non-conventional health industry. This paper also adds to the brand manager's knowledge of how to build and harness credibility, quality, and satisfaction to increase brand equity in the non-conventional health industry.
\end{abstract}

Keywords: Customer Satisfaction; Brand Credibility; Brand Equity; Perceived Quality; Herbal medicine.

\section{Introduction}

In recent years, herbal medicines have gained much attention worldwide due to their widespread consumption alongside modern healthcare delivery drugs. Herbal medicinal products relate to processed or raw plant materials and herbal medicinal products with therapeutic or human benefits obtained from one or more plants (WHO, 2007). WHO (2008) reported that roughly one-third of the residents in the industrialized world had patronized complementary or alternative medicine once in their lifetime. Research also revealed that more than half of the people in emerging countries still use herbal therapies to treat their ailments (WHO, 2011). It has also been estimated that approximately $80 \%$ of Ghanaians depend on herbal medicines to treat diseases and illnesses (UNDP, 2007). Broadly, herbal medicinal products are used to combat minor sicknesses, manage chronic diseases, and maintain health fitness (referenced by Naresh \& Reddy, 2016). Identifying the increasing demand for herbal medicines in the Cape Coast metropolis, non-conventional health practitioners have adopted diverse product and process innovations. The product innovations are explicitly seen in the manufacturing of assorted herbal medicines such as tablets, capsules, creams and mixtures. Those operating on a large scale employ various modern manufacturing equipment such as tubefilling machines to package creams, devices for bottling liquid preparations with complete seals, semiautomated capsule-filling machines for capsules, and labeling machines (Essegbey, Awuni, Essegbey, Akuffobea \& Mica, 2014). The manufacturing and sale of plant medicinal products in Cape Coast are currently overseen by the Food and Drugs Authority (FDA) and the Traditional Medicine Practice Council (TMPC). The herbal medicinal products are retailed as non-prescription medications at pharmacies, over-the-counter medicine stores, herbal stores and clinics operated by non-conventional health practitioners (WHO, 2011; Essegbey et al., 2014).

The proliferation of herbal therapies in the metropolis has given rise to stiff competition resulting in abysmally low prices and hence, a reduction in profit in the industry. It has also been emphasized that favorable perceived brand quality, high level of brand credibility, and satisfied customers can increase brand equity in the market (Ameri \& Behnam, 2014; Shamim \& Butt, 2013; Pappu \& Quester, 2006; Yoo, Donthu \& Lee, 2000). Increased brand equity can create a platform for non-conventional medicine firms to insulate themselves against competitive pressures and entry of rival firms, charge a premium price, endure a marketing crisis and gain a competitive advantage to survive in the industry (Farquhar, 1989; Aaker, 1992). Although the importance of perceived quality, brand credibility, and customer satisfaction to OBE has received much attention (e.g., Ameri \& Behnam, 2014; Shamim \& Butt, 2013; Pappu \& Quester, 2006; Yoo et 
al., 2000), there is scanty or no investigation on the brand credibility`s intervening role in the effect of quality and satisfaction on brand equity, especially in the non-conventional health industry. Therefore, this paper aimed to examine the intervening role of brand credibility in the impact of quality and satisfaction on the value of the brands in the non-conventional health industry in Cape Coast. This paper, therefore, extends the current brand theory by bringing to fore the intervening role of brand credibility in the effect of brand quality and satisfaction on equity, particularly in the non-conventional health industry. Besides, this study equips the brand managers with knowledge about building and harnessing brand quality, satisfaction, and credibility to enhance the value of the brands in the non-conventional health industry in the Cape Coast metropolis.

\section{Literature Review}

Brand Equity: A brand with high equity is recognized as one of the enduring and strategic assets because it provides a long-term cash flow for a firm. Brand equity has been defined as an increased value offered by branding to an offering (Farquhar, 1989). In the author`s view, healthy brands with high equity create a competitive advantage, resistance to competitive actions, premium price, a barrier to entry of rival firms, and power to survive during marketing crises, such as a change in tastes. Research also found that brand equity positively affects customers readiness to pay a higher price, word-of-mouth behavior, and repeat purchases of financial services products (Rambocas, Kirpalani \& Simms, 2018). In general, the brand equity concept has been studied in three different viewpoints, namely financial, customer and employer-related approaches. The financially-based view explicitly evaluates a brand's value for accounting purposes, mergers, acquisitions and divestiture (Keller, 2013). Consequently, brand equity relates to the incremental cash flow realized from selling a branded product exceeding its unbranded version (Simon \& Sullivan, 1993). In this perspective, brand equity is considered an asset that a firm can sell and buy.

On the other hand, employer-based motivations look at brand equity in terms of human resource perspective and relate to a set of functional, economic, and psychological values provided through employment and are identified with the employed company (Ambler \& Barrow, 1996). Lastly, customer-based brand equity (CBBE) indicates the differential outcomes of brand knowledge on consumer responses due to its marketing campaigns (Keller, 2013). The strength of a brand is manifested in what customers have stored in their minds about the brand. Guided by the associative network memory framework, brand knowledge underlies the customer-based brand equity (CBBE) and relates to the brand node in memory with different associations attached to it. The brand knowledge comprised brand awareness and image, which are considered the primary sources of CBBE. Thus, CBBE occurs when a brand demonstrates a high level of awareness and strong, positive and distinctive associations (ibid). Aaker (1996) also viewed brand equity as a package of assets and liabilities attached to a brand that decrease or increase the product's value to a business and its customers. However, Yoo et al. (2000) extended Aaker's framework by creating a separate construct known as overall brand equity (OBE) to indicate each dimension's contribution to brand equity. In their view, OBE refers to the difference in the buyer`s decision to choose between a branded product and its unbranded type.

\section{Research Hypotheses}

Customer Satisfaction: Developing greater satisfaction is regarded as one of a business's core objectives because it creates a platform for successful customer retention. Customer satisfaction looks at the degree to which a product's performance matches or surpasses a customer`s expectation (Ferrell \& Hartline, 2011; Lovelock \& Wirtz, 2016). Alternatively, Kotler and Keller (2012) defined customer satisfaction as a degree of contentment or displeasure resulting from comparing a product's perceived performance to expectations. Customer satisfaction stems from the customer`s post-purchase judgment of a product or service. The expectancy-disconfirmation framework has been the basis of determining customer satisfaction. This model suggests that consumers develop a product's performance expectations before purchasing a product or service. Consumers then compare the product's perceived performance during and after consumption to their expectations (Lovelock \& Wirtz, 2016). If the perceived performance falls short of, matches or exceeds expectations, negative disconfirmation, confirmation and positive disconfirmation occur, respectively. In other words, if the customers ' perceptions of product performance are in line with, worse and better than as it is anticipated, the customers are satisfied, dissatisfied and delighted, respectively. 
Customers' expectations arise from past purchase exposures, advice from friends and associates, and marketers and competitors' activities (Kotler \& Keller, 2012). Greater satisfaction is linked to customer loyalty, repeated purchases, positive word-of-mouth, premium price, increase in the volume of purchases and less customer switching behavior (Kotler \& Keller, 2012; Ferrell \& Hartline, 2011). Prior research also highlighted that customer satisfaction significantly influences repeated patronage, intention to pay a premium price, and word-of-mouth (Ranaweera \& Prabhu, 2003; de Matos \& Rossi, 2008; Rambocas et al., 2018). Studies also reported that customer satisfaction directly impacts brand credibility (Ursula, Rebekah, Syed \& Gary, 2016) and OBE (Pappu \& Quester, 2006). Hence, the hypotheses postulated are:

H1: There will be a significant and direct relationship between customer satisfaction and brand credibility.

H2: There will be a significant and direct relationship between customer satisfaction and brand equity.

Perceived Quality: Enhanced perceived quality is acknowledged as a strategic goal of most firms because of its direct contribution to profitability. Quality has been defined by different professionals as "fitness for use", "conformance to requirements", and "freedom for variations" (Kotler \& Keller, 2012). Perceived quality has been described as perceptions of a product's total superiority compared to its stated use and a set of alternatives (Aaker, 1991). Zeithaml (1988) also viewed perceived quality as the customer's assessment of a product's total excellence. However, perceived quality is quite different from similar quality concepts such as objective quality, manufacturing quality and product quality. Objective quality reflects the degree to which a product offers excellent service, whereas manufacturing quality indicates conformance to the industry`s requirements. Product quality is described as the character and amount of ingredients, services and attributes used (Aaker, 1991). The author believes that objective quality should be improved to strengthen the perceived product quality.

Perceived quality is typically based on the underlying elements such as performance, reliability, durability, serviceability, fit and finish, features, and conformance to the specification (ibid). Aaker (1992) also asserted that high perceived quality significantly enhances market share, line extensions, brand differentiation, premium price, and overall profitability. The author further suggested that increased perceived quality reinforces customer satisfaction and brand equity. Studies also show that perceived quality directly affects satisfaction (Bilal \& Malik, 2014), brand equity (Yoo et al., 2000; Oppong \& Phiri, 2018), and brand credibility (Rizwan, Javed, Aslam, Khan, \& Bibi, 2014). Hence, the hypotheses formulated are:

H3: There will be a significant and direct relationship between perceived quality and customer satisfaction.

H4: There will be a significant and direct relationship between perceived quality and brand credibility.

H5: There will be a significant and direct relationship between perceived quality and brand equity.

Brand Credibility: Credible brands are considered vital assets of an organization because they positively influence consumer brand choice and loyalty. Erdem and Swait (2004) explained brand credibility as the believability of a brand's product position message, which requires continuous delivery of its promise. According to the authors, brand credibility entails expertise and trustworthiness. Trustworthiness relates to the brand's readiness to meet its intended use, whilst expertise looks at how capable it is in delivering its promise. Alternatively, Keller (2013) described brand credibility as the degree of authenticity of the brand and encompassed expertise, attractiveness and trustworthiness. The brand's trustworthiness and expertise are the combined effect of a firm`s previous and present marketing activities and strategies (Erdem \& Swait, 2004). In their view, credible brands can be developed and shaped by increasing the brands' investments and providing consistency and clarity of marketing strategies and activities to assure consumers that the brand`s information is true and reliable and that the promise is fulfilled. Consequently, consistency, clarity and brand investments underlie the concept of brand credibility.

The significant role of credible brands is heightened in a market where imperfect and asymmetric product information exists, which leads to high consumer information acquisition costs and perceived risks. Therefore, a credible brand offers value to customers by reducing the information cost and perceived risks, thereby enhancing the product's expected utility. A credible brand can also strengthen brand equity by generating positive attribute perceptions (Erdem \& Swait, 1998). Past studies also show that brand credibility has a significant positive effect on brand equity (Erdem \& Swait, 1998; Shamin \& Butt, 2013). Studies also found that perceived quality and customer satisfaction directly impact brand credibility (Rizwan 
et al., 2014; Ursula et al., 2016), and in turn, brand credibility strengthens the OBE (Erdem \& Swait, 1998; Shamin \& Butt, 2013). Consequently, the hypotheses postulated are:

H6: There will be a significant and direct relationship between brand credibility and brand equity.

H7: Brand credibility mediates the relationship between perceived quality and brand equity.

H8: Brand credibility mediates the relationship between customer satisfaction and brand equity.

Conceptual Model: Here, the conceptual framework offers a graphical explanation of the key constructs and the posited inter-relationships among them (Miles, Huberman \& Saldăna, 2014). In this research, customer satisfaction and perceived quality are independent variables, and brand credibility is an intervening variable, while OBE is a dependent variable. The conceptual framework depicted in Figure 1 indicates that satisfaction and quality directly influence brand credibility, and in turn, credibility positively affects equity. Brand credibility means the believability of a brand's product message, which entails trustworthiness and expertise (Erdem \& Swait, 2004). Perceived quality measures the perceptions of a product's total superiority compared to its stated use and the alternatives (Aaker, 1991). Moreover, OBE relates to the difference in a buyer`s decision to choose between a branded product and its unbranded type (Yoo et al., 2000). Customer satisfaction also relates to the degree of contentment or displeasure, resulting from comparing the perceived product's performance to expectations (Kotler \& Keller, 2012).

Figure 1: Conceptual Model

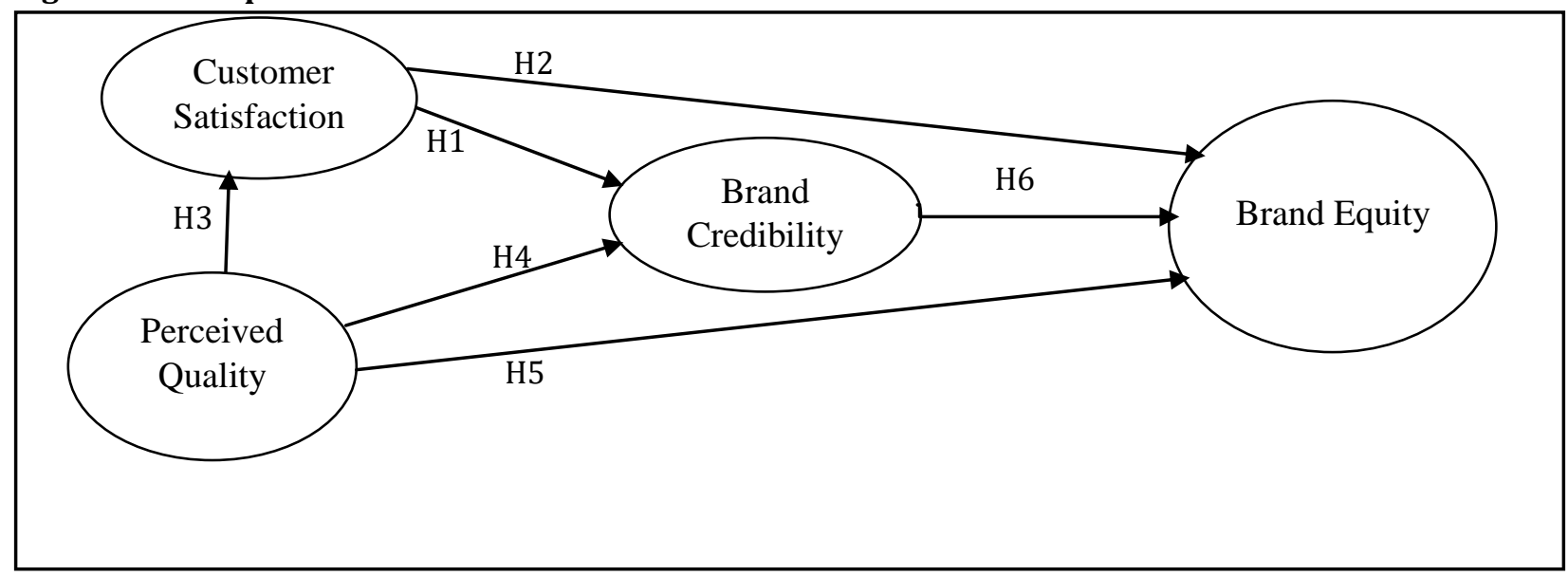

Source: Developed by the Researcher

\section{Research Methodology}

The research methodology used to assess the hypotheses posited to address the study's goal is explained below.

Population and Sample: The study`s population comprises approved made-in-Ghana herbal medicines, 26 herbal retail stores and 854 customers who purchase herbal medicinal products for their personal use from the retail stores. The number of herbal retail outlets was obtained from TMPC in Cape Coast, while that of the customers was from the herbal retail stores. Using Krejcie and Morgan's (1970) guide for calculating sample size, the researcher used 265 samples of the customers.

Test Scale Development and Administration: The research participants' perceptions of satisfaction, credibility, quality, and OBE were measured by using a five-point survey questionnaire anchored on $1=$ strongly disagreed, and $5=$ strongly agree. This type of questionnaire was adopted because the data obtained permit statistical analysis, and the findings are much easier to interpret (Creswell, 2014). The indicator items used in this study were obtained from the previous research. The indicator items of brand credibility were from Erdem and Swait (2004), quality from Yoo et al. (2000), and Gil, Andres \& Martinez (2007), satisfaction from He, Li and Harris (2012), and Delgado-Ballester and Munuera-Alemán (2005), and OBE from Yoo et al. (2000). The research assistants distributed the questionnaires to the customers in front of the stores through 
a systematic sampling method. This technique provides an opportunity to recruit research participants without firsthand information about them in the sampling frame (Malhotra, Nunan \& Birks, 2017). The customers were asked first if they had used herbal medicine before to qualify to participate in the study. The purpose was to obtain the customers' perceptions of credibility, quality, satisfaction, and OBE of the herbal medicines sold in the metropolis.

\section{Data Analysis and Results}

The statistical techniques used to analyze the data collected were descriptive statistics, exploratory factor analysis (EFA), and structural equation modelling (SEM) using SPSS Amos 20.

Descriptive Statistics: Descriptive statistics were employed to present the sample characteristics concerning age, gender, and education. Two hundred and thirty (230) questionnaires were administered to the sampled customers. However, 208 questionnaires were utilized due to the respondent's invalid responses. The results show that most of the research participants were male, between 26 and 35 years, and had attained secondary education. That is, 104 (50.7\%) were male, 81(39.1\%) were between 26 and 35 years, and 74 (36.5\%) possessed secondary education.

Exploratory Factor Analysis: The EFA aimed to determine whether the scale items employed correlate with their corresponding latent variables. Overall, 17 indicators were used for the EFA through the principal axis factoring, using Varimax rotation procedures. The results in Table 1 reveal that Kaiser-Meyer-Olkin (KMO) Measure of Sampling Adequacy of .818 and Bartlett's Test of Sphericity at $\mathrm{p}<.05$, suggesting good EFA (Hair, Black, Babin \& Anderson, 2014; Pallant, 2013). Furthermore, the EFA, through the rotated factor matrix, extracted a four-factor model. Factor 1 represents credibility, 2 is OBE, 3 is satisfaction, and 4 is quality. A total of 14 indicators were acceptable because loadings less than .30 and those that cross-loaded with other factors were eliminated (Floyd \& Widaman, 1995). The factor loadings ranged between .625 and .926 . The four latent variables had eigenvalues above 1.0 and predicted 64.27 percent of the total variance. Besides, coefficient alpha was employed to identify the indicators' internal consistency reliability to eliminate those with low inter-item correlations. The findings in Table 1 suggest that all the latent variables have coefficients above .70, ranging from .812 to .873 , providing proof of internal consistency (Tavakol \& Dennick, 2011).

Table 1: Results of Exploratory Factor Analysis

\begin{tabular}{|c|c|c|c|c|c|}
\hline & \multicolumn{4}{|l|}{ Factor } \\
\hline \multicolumn{2}{|c|}{ Scale Items } & & 2 & 3 & 4 \\
\hline $\mathrm{BC} 2$ & $\mathrm{X}$ delivers what it promises & .766 & & & \\
\hline BC4 & X's product claims are believable & .756 & & & \\
\hline BC3 & $\mathrm{X}$ has the ability to deliver what it promises & .723 & & & \\
\hline BC5 & $\begin{array}{l}\text { Over time, my experiences with } \mathrm{X} \text { had led me to expect } \\
\text { it to keep its promises }\end{array}$ & .670 & & & \\
\hline BC1 & $\mathrm{X}$ has a name you can trust & .625 & & & \\
\hline BE3 & $\begin{array}{l}\text { It makes sense to buy X instead of any other brand even } \\
\text { if they are the same }\end{array}$ & & .855 & & \\
\hline BE4 & $\begin{array}{l}\text { If another brand is not different from } \mathrm{X} \text { in any way, it } \\
\text { seems smarter to purchase } \mathrm{X}\end{array}$ & & .771 & & \\
\hline BE2 & $\begin{array}{l}\text { Even if another brand has the same characteristics as X, } \\
\text { I would prefer to buy X }\end{array}$ & & .746 & & \\
\hline CS2 & I am very pleased with $X$ & & & .810 & \\
\hline CS3 & I am very delighted with $\mathrm{X}$ & & & .772 & \\
\hline CS1 & I am completely satisfied with X & & & .720 & \\
\hline CS4 & I am not very disappointed with $\mathrm{X}$ & & & .667 & \\
\hline PQ4 & The likelihood that X would be functional is very high & & & & .926 \\
\hline PQ3 & $\mathrm{X}$ is very reliable & & & & .685 \\
\hline \multicolumn{2}{|r|}{ s Alpha } & .861 & .873 & .812 & 839 \\
\hline \multicolumn{2}{|c|}{ Eigenvalues } & 5.543 & 2.440 & 1.660 & 1.283 \\
\hline
\end{tabular}


Percentage of Variance Explained 32.606

Percentage of Total Variance Explained $=64.27$

KMO $=0.804 ;$ Bartlett's Test of Sphericity: X2 $=1760.203 ; \mathrm{DF}=136 ; \mathrm{p}<0.001$

Notes: $\mathrm{X}$ is the focal brand.

Structural Equation Modelling: The SEM was adopted to evaluate the hypotheses formulated in this paper. This analytical tool was used because the data collected involve unobserved variables measured by multiple indicators. Moreover, SEM is regarded as an efficient and suitable multivariate statistical method for analyzing several equations simultaneously. SEM also accounts for overall model fit and measurement errors linked to each indicator (Hair et al., 2014; Bryne, 2016). Guided by Bryne's (2016) suggestion for conducting C-SEM, the CFA was performed before the path model.

Confirmatory Factor Analysis: The CFA was performed to confirm the results of the EFA. In the CFA, indicators with standardized estimates below .50 were eliminated to support convergent validity (Hair et al., 2014). Hence, a test item of brand credibility and satisfaction was deleted from the analysis. Table 2 presents the CFA results, showing that 12 indicators loaded on the four variables and all the standardized estimates were significant, ranging between .615 and .884 , indicating construct validity (ibid). The Chi-square test (CMIN $=94.668, \mathrm{df}=48, \mathrm{p}=.000$ ) was not acceptable but the rest of the fit measures were admissible. Goodness-of-Fit Index (GFI) = .936; Standardised Root Mean Square Residual (SRMR) = .051; Normed ChiSquare statistic $(\mathrm{CMIN} / \mathrm{DF})=1.972$; Comparative Fit Index $(\mathrm{CFI})=.956$; Tucker-Lewis Index $(\mathrm{TLI})=.939$; Incremental Fit Index (IFI) = .956; and Normed Fit Index (NFI) = .915 proved to be satisfactory (Hu \& Bentler, 1999; Kline, 2015; Hair et al., 2014).

Table 2: Results of Measurement Model

\begin{tabular}{lcc}
\hline Latent Variables & Standardised Loadings & t-values \\
\hline Brand Credibility & & \\
BC1 & .615 & $-\mathrm{a}$ \\
BC3 & .663 & 7.612 \\
BC4 & .824 & 8.722 \\
BC5 & .809 & 8.654 \\
Customer Satisfaction & & \\
CS4 & .643 & $-\mathrm{a}$ \\
CS3 & .783 & 7.492 \\
CS1 & .732 & 7.529 \\
OBE & & \\
BE2 & .807 & $-\mathrm{a}$ \\
BE3 & .884 & 13.499 \\
BE4 & .820 & 12.738 \\
Perceived Quality & & \\
PQ4 & .875 & $-\mathrm{a}$ \\
PQ3 & .829 & 7.596 \\
\hline Notes: $=$ path paran
\end{tabular}

Notes: a $=$ path parameter was set to 1 ; therefore, no t-values were estimated; all standardized regression weights are significant at $\mathrm{p}=0.001$ level.

Construct Validity Analysis: Construct validity was determined through convergent validity and discriminant validity. Fornell and Lacker's (1981) criterion and average variance extracted (AVE) were adopted to test convergent validity and discriminant validity, respectively. The results in Table 3 show that all the AVEs exceeded .50, providing support to convergent validity (Bagozzi \& Yi, 1988). Besides, the square root of the AVEs exceeded the squared correlations between one latent variable and another, supporting discriminant validity (Fornell \& Lacker, 1981). 
Table 3: Results of Construct Validity

\begin{tabular}{llllll}
\hline Latent Variables & AVEs & CS & PQ & BC & OBE \\
\hline Customer Satisfaction (CS) & .521 & $.722^{* *}$ & & & \\
Perceived Quality (PQ) & .727 & .030 & $.853^{* *}$ & & \\
Brand Credibility (BC) & .538 & .081 & .153 & $.733^{* *}$ & \\
OBE (OBE) & .702 & .032 & .194 & .274 & $.838^{* *}$ \\
\hline
\end{tabular}

Notes: AVE $=$ Average Variance Extracted; ${ }^{* *}=$ Square root of AVEs; Off-diagonal estimates measure the squared inter-construct correlations.

Path Analysis: The path analysis was used to test the hypotheses proposed. The results of the path analysis show that the Chi-square statistic (CMIN $=94.668, \mathrm{DF}=48, \mathrm{p}=.000)$ was not satisfactory. However, the $\mathrm{CMIN} / \mathrm{DF}=1.972 ; \mathrm{GFI}=.936 ; \mathrm{TLI}=.939 ; \mathrm{IFI}=.956 ; \mathrm{CFI}=.956 ; \mathrm{NFI}=.915 ; \mathrm{SRMR}=.051 ; \mathrm{RMSEA}=.069$ confirmed the path analysis. The summary of the path analysis is shown in Table 4, which demonstrate that customer satisfaction is directly related to credibility $(\beta=.224, p=009)$ at $p<.05$, supporting $H 1$. However, the direct relationship between satisfaction $(\beta=.015, \mathrm{p}=.847)$ and OBE is not statistically significant and thus, rejecting $H 2$. Likewise, quality is directly related to satisfaction $(\beta=.173, \mathrm{p}=.049)$, credibility $(\beta=.352$, $\mathrm{p}=.000)$, and OBE $(\beta=.278, \mathrm{p}=.000)$ at $\mathrm{p}<0.05$, confirming $\mathrm{H} 3, H 4$ and $H 5$ respectively. Finally, the credibility positively affects OBE $(\beta=.411, \mathrm{p}=.000)$ at $\mathrm{p}<.05$ significance level. This outcome provides support to $H 6$.

Table 4: Results of the Path Analysis

\begin{tabular}{lllllll}
\hline Hypotheses & Structural Relations & & & $\begin{array}{l}\text { Standardized } \\
\text { Estimate }\end{array}$ & C. R. & p-values \\
& & & & .603 & .009 \\
H1 & Brand Credibility & $<----$ & Customer Satisfaction & .224 & .603 & .847 \\
H2 & Brand Equity & $<---$ & Customer Satisfaction & .015 & .193 \\
H3 & Customer Satisfaction & $<----$ & Perceived Quality & .173 & 1.972 & .049 \\
H4 & Brand Credibility & $<----$ & Perceived Quality & .352 & 4.021 & .000 \\
H5 & Brand Equity & $<----$ & Perceived Quality & .278 & 3.396 & .000 \\
H6 & Brand Equity & $<----$ & Brand Credibility & .411 & 4.574 & .000 \\
\hline
\end{tabular}

Mediation Testing: This researcher also investigated the brand credibility`s mediating role in the path between satisfaction and OBE (H7) and quality and OBE (H8). Following Baron and Kenny's (1986) mediational model, which involves; (1) regressing the mediator on the independent variable; (2) the dependent variable on the independent variable; and (3) the dependent variable on both the independent variable and the mediator. The mediational relationships stipulated were tested by using the bootstrap resampling approach. The analysis show that the direct relationship between satisfaction $(B=.015, p=.870)$ and $\mathrm{OBE}$ is not statistically significant at $\mathrm{p}<.05$. However, the indirect effect of satisfaction $(ß=.092, \mathrm{p}=$ $.013)$ on OBE is significant at $p<.05$. These results show that credibility completely mediates the path between satisfaction and OBE. More so, the analysis reveals that the direct effect of quality $(\beta=.278, p=.001)$ on OBE is significant at $\mathrm{p}<.05$. The data analysis demonstrates that the indirect effect of quality $(ß=.163, \mathrm{p}=$ .000 ) on OBE is significant at $\mathrm{p}<.05$ level. The data analysis shows that brand credibility partially mediates the path between perceived quality and OBE in the non-conventional health market.

\section{Discussion}

This paper aimed to determine the role of satisfaction, quality, and credibility in strengthening OBE in the non-conventional health industry. The study revealed that satisfaction contributes to enriching herbal medicines' credibility in the non-conventional health industry. This result concurs with a previous study (Ursula et al., 2016); indicating that increased satisfaction potentially strengthens a brand's credibility. This outcome suggests that customers who were delighted believed that the brand is trustworthy and could deliver its intended purpose in the non-conventional health market. Again, the research confirmed that favorable perceived quality enhances customers' satisfaction with a brand. This outcome confirmed prior studies (Aaker, 1992; Bilal \& Malik, 2014), contending that an improved perceived quality significantly increases customers`satisfaction. 
Again, consistent with past research findings (Rizwan et al., 2014), this paper found that perceived quality positively affects the credibility of herbal medicines sold in the non-conventional health market. A brand perceived by consumers as of higher quality enriches the brand's trustworthiness and expertise in the market. Besides, the perceived quality was found to have a positive effect on the OBE of herbal medicines distributed in the non-conventional health market. This study's outcome concurs with earlier studies (Yoo et al., 2000; Oppong \& Phiri, 2018), suggesting that perceived quality supports OBE. The research also indicates that perceived quality $(\beta=.352)$ has a greater influence on credibility than satisfaction. Consistent with past studies`results (Erdem \& Swait, 1998; Shamin \& Butt, 2013), this paper also revealed that brand credibility directly affects the OBE.

In line with a past study (Erdem \& Swait, 1998), this paper demonstrates that credibility $(\beta=.411)$ has a stronger influence on OBE than any other constructs. The study also shows that brand credibility fully mediates the path between satisfaction and OBE and partly contributes to the impact of perceived quality on OBE in the non-conventional health market. Thus, high brand credibility plays a vital role in supporting customers ' perceptions of quality and satisfaction, which, in turn, enriches the OBE in the non-conventional health market.

\section{Conclusion and Recommendations}

Conclusion: This paper aimed to identify the effect of satisfaction, quality and credibility on OBE, and more importantly, the mediating role of credible brands in the path between quality, satisfaction, and OBE in the non-conventional health industry. The study established that quality and satisfaction positively influence the brands' credibility in the non-conventional health market. The paper further points out that perceived quality more significantly affects credibility than satisfaction in the non-conventional health market. The research also revealed that credibility and quality contribute immensely to OBE. However, brand credibility has a more substantial influence on equity than any other variable in this study. More importantly, the study confirmed that brand credibility perfectly mediates the effect of satisfaction on OBE but partly contributes to the role of quality in strengthening the OBE in the non-conventional health market. Therefore, the research concludes that quality, credibility, and satisfaction are essential ingredients of OBE, which can build and manage OBE of herbal medicines in the Cape Coast non-conventional health industry.

Recommendations: The following recommendations are made which have managerial relevance to the strategic decisions of non-conventional health practitioners in the industry. The research established that customer satisfaction enriches herbal medicines' credibility in the non-conventional health market. Therefore, non-conventional health practitioners should increase the customer`s satisfaction to strengthen their credibility in the Cape Coast market. Again, the research pointed out that favorable perceived quality significantly influences customers' satisfaction, brands' credibility and the OBE in the non-conventional health industry. Because of this, the non-conventional health practitioners should channel their efforts to increase perceived quality to support the customers` satisfaction, brands` credibility, and OBE in the market.

This paper also revealed that brand credibility directly affects the OBE in the non-conventional health industry. This paper further demonstrates that credibility $(\beta=.411)$ has a more substantial impact on OBE than any other constructs. Consequently, non-conventional health practitioners should invest more of their resources to build their brand's credibility to strengthen their overall value in the market. The study also found that brand credibility perfectly mediates the impact of customer satisfaction on OBE and partially contributes to the effect of perceived quality on OBE in the non-conventional health industry. Realizing the critical role of brand credibility in the impact of satisfaction and quality on OBE, the non-conventional health practitioners should develop and harness brand credibility to reinforce satisfaction and quality to increase OBE in the Cape Coast non-conventional health industry.

Limitations and Direction for Future Research: The non-conventional health market includes in-store and online environments, but data were gathered from only the physical marketplace. Future research should consider both online and in-store environments. The study also looked at the plant medicines produced and packaged by Ghanaian firms, and hence, CAM was not part of the study. Future studies should involve both CAM and non-conventional medicines. The quantitative method was relied on to address this research's goal, 
and therefore, future research should look at mixed methods to improve its generalisability. Furthermore, the study considered only processed finished herbal medicinal products. Future research should consider raw herbs and herbal preparations to ascertain the customers' perceptions of quality, brands' credibility, satisfaction, and OBE of the herbal medicines distributed in the market.

\section{References}

Aaker, D. A. (1992). The Value of Brand Equity. Journal of Business Strategy, 13(4), 27-32.

Aaker, D. A. (1991). Managing Brand Equity: Capitalising on the Value of Brand Name. New York: The Free Press.

Aaker, D. A. (1996). Measuring Brand Equity across Products and Markets. California Management Review, 38(3), 102-120.

Ambler, T. \& Barrow, S. (1996). The Employer Brand. Journal of Brand Management, 4(3), 185-206.

Ameri, H. S. \& Behnam, M. (2014). The Effect of Brand Credibility on Consumers` Perceptions about Brands and their Purchasing Behaviours in Sports Goods. Sport Science, 7(2), 50-57.

Bagozzi, R. P. \& Yi, Y. (1988). On the Evaluating Structural Equation Models. Journal of Academy of Marketing Research, 16(1), 074-094.

Baron, R. M. \& Kenny, D. A. (1986). The Moderator-Mediator Variable Distinction in Social Psychology Research: Conceptual, Strategic, and Statistical Considerations. Journal of Personality and Social Psychology, 51(6), 1173-1182.

Bilal, A. \& Malik, F. M. (2014). Impact of Brand Equity and Brand Awareness on Customer Satisfaction. International Journal of Modern Management \& Foresight, 1(10), 287-303.

Bryne, B. M. (2016). Structural Equation Modelling with AMOS: Basic Concepts, Applications and Programming, ( $3^{\text {rd }}$ Ed.). New York: Taylor \& Francis.

Creswell, J. W. (2014). Research Design: Qualitative, Quantitative, and Mixed Methods Approaches, (4 ${ }^{\text {th }}$ Ed.). California: SAGE Publications.

de Matos, C. A. \& Rossi, C. A. V. (2008). Word-of-Mouth Communications in Marketing: A Meta-Analytic Review of the Antecedents and Moderators. Journal of Academy of Marketing Science, 36, 578-596.

Delgado-Ballester, E. \& Munuera-Alemán, J. L. (2005). Does Brand Trust Matter to Brand Equity? Journal of Product \& Brand Management, 14(3), 187-196.

Erdem, T. \& Swait, J. (1998). Brand Equity as a Signaling Phenomenon. Journal of Consumer Research Psychology, 7(2), 131-157.

Erdem, T. \& Swait, J. (2004). Brand Credibility, Brand Consideration, and Brand Choice. Journal of Consumer Research, 13, 191-198.

Essegbey, G. O., Awuni, S., Essegbey, I. T., Akuffobea, M. \& Mica, B. (2014). Country Study on Innovations, Intellectual Property and Informal Economy: Traditional Medicines in Ghana, (13 ${ }^{\text {th }}$ Ed.). World International Property Organization: Geneva.

Farquhar, P. H. (1989). Managing Brand Equity. Marketing Research, 1(3), 24-33.

Ferrell, O. C. \& Hartline, M. C. (2011). Marketing Strategy, (5 ${ }^{\text {th }}$ Ed.). USA: Cengage Learning.

Floyd, F. J. \& Widaman, K. F. (1995). Factor Analysis in the Development and Refinement of Clinical Assessment Instrument. Psychological Assessment, 7(3), 286-299.

Fornell, C. \& Larcker, D. F. (1981). Evaluating Structural Equation Models with Unobservable Variables and Measurement Error. Journal of Marketing Research, 18(1), 39-50.

Gil, R. B., Andres, E. F. \& Martinez, E. S. (2007). Family as a Source of Customer-Based Brand Equity. Journal of Product \& Brand Management, 16(3), 188-199.

Hair, J. H. Jr., Black, W. C., Babin, B. J. \& Anderson, R. E. (2014). Multivariate Data Analysis, (7th Ed.). England: Pearson Education.

He, H., Li, Y. \& Harris, L. (2012). Social Identity Perspective on Brand Loyalty. Journal of Business Research, 65, 648-657.

Keller, K. L. (2013). Strategic Brand Management: Building Measuring and Managing Brand Equity, Global Edition, (4 ${ }^{\text {th }}$ Ed.). England: Pearson Education.

Kline, R. B. (2015). Principles and Practice of Structural Equation Modelling, (2 ${ }^{\text {nd }}$ Ed.). New York: Guilford Press.

Kotler, P. \& Keller, K. L. (2012). Marketing Management, (14th Ed.). New Jersey: Pearson Education. 
Krejcie, R. V. \& Morgan, D. V. (1970). Determining Sample Size for Research Activities. Education \& Psychological Measurement, 30, 607-610.

Lovelock, C. \& Wirtz, J. C. (2016). Services Marketing: People, Technology and Strategy, (8 ${ }^{\text {th }}$ Ed.). USA: Pearson Education.

Malhotra, N. K., Nunan, D. \& Birks, D. F. (2017). Marketing Research: An Applied Approach, (5th Ed.). United Kingdom: Pearson Education.

Miles, M. B., Huberman, A. M. \& Saldaña, J. (2014). Qualitative Data Analysis: A Methods Sourcebook, (3 ${ }^{\text {rd }}$ Ed.). USA: SAGE Publication.

Naresh, B. \& Reddy, D. B. S. (2016). Impact of Perception on Customer Purchase Behaviour of Herbal Product in India. Indian Journal of Research, 5(6), 233-235.

Oppong, P. K. \& Phiri, M. A. (2018). Measuring Customer-Based Brand Equity in Traditional Herbal Medicine Market in Kumasi, Ghana. African Journal of Business \& Economic Research, 13(3), 115-133.

Pallant, J. (2013). SPSS Survival Manual: A Step by Step Guide to Data Analysis using IBM SPSS, (5 ${ }^{\text {th }}$ Ed.). New York: McGraw-Hill Education.

Pappu, R. \& Quester, P. (2006). Does Customer Satisfaction lead to Improved Brand Equity? An Empirical Examination of Two Categories of Retail Brands. Journal of Product and Brand Management, 15(1), 414.

Rambocas, M., Kirpalani, V. M. \& Simms, E. (2018). Brand Equity and Customer Behavioural Intentions: A Mediated Moderated Model. International Journal of Bank Marketing, 36(1), 19-40.

Ranaweera, C. \& Prabhu, J. (2003). On the Relative Importance of Customer Satisfaction and Trust as Determinants of Customer Retention and Positive Word-of-Mouth. Journal of Targeting, Measurement \& Analysis for Marketing, 12(1), 82-90.

Rizwan, M., Javed, P. A., Aslam, J., Khan, R. \& Bibi, H. (2014). The Relationship of Brand Commitment, Brand Credibility, Perceived Quality, Customer Satisfaction, and Brand Loyalty: An Empirical Study on Stylo Shoes. Journal of Sociological Research, 5(2), 378-404.

Shamim, A. \& Butt, M. M. (2013). A Critical Model of Brand Experience Consequences. Asia Pacific Journal of Marketing and Logistics, 25(1), 102-117.

Simon, C. J. \& Sullivan, M. V. (1993). The Measurement and Determinants of Brand Equity: A Financial Approach. Marketing Science, 12(1), 28-52.

Tavakol, M. \& Dennick, R. (2011). Making Sense of Cronbach's Alpha. International Journal of Medical Education, 2, 53-55.

UNDP (2007). The Ghana Human Development Report: Towards a More Inclusive Society, Ghana. (http://www.hrd.undp.org/sites/default/files/nhdr_ghana.pdf: Retrieved July 7, 2020).

Ursula, B., Rebekah, R. B., Syed, F. E. H. \& Gary, M. (2016). The Impact of Service Failure on Brand Credibility. Journal of Retailing and Consumer Sciences, 31, 62-71.

WHO (2007). WHO Guidelines for Assessing the Quality of Herbal Medicines with Reference to Contaminants and Residues. Geneva: WHO Press.

WHO (2008). Traditional Medicine. Fact Sheet No.134 (http://www.who.int/medicines/areas/traditional/definitions/en/pdf: Retrieved June 4, 2020)

WHO (2011). Traditional Medicines, Global Situation, Issues, and Challenges. The World Medicines Situation, ( $3^{\text {rd }}$ ed.), Geneva (http://www.who.int/medicines/areas/policy/world_medicines_situation/WMS_ch6_wPri cing_v6.pdf: Retrieved June 14, 2020).

Yoo, B., Donthu, N. \& Lee, S. (2000). An Examination of Selected Marketing Mix Elements and Brand Equity. Journal of the Academy of Marketing Science, 28(2), 195-211.

Zeithaml, V. A. (1988). Consumer Perceptions of Price, Quality, and Value: A Means-End Model and Synthesis of Evidence. Journal of Marketing, 52, 2-22. 